\title{
Study on Impact of Foreign Direct Investment on Logistics Transport Development: HCM, Vietnam Case
}

\section{Vu Thi Kim Hanh}

\author{
University of Economics and Law, \\ Vietnam National University Ho Chi Minh City \\ *Corresponding author details: Vu Thi Kim Hanh; \\ vtkhanh.ti@gmail.com, hanhvtk20702@sdh.uel.edu.vn
}

\begin{abstract}
The Foreign Direct investment (FDI) plays crucial role on an economy, especially the developing countries like Vietnam. FDI impacts strongly and deeply on the economic sector in a nation. This paper has an objective to measure the impact of FDI on logistics transport development in Ho Chi Minh (HCM), Vietnam by using multivariate regression. The important results are: while registered FDI capital and number of FDI projects have impact, operating FDI capital does not impact productivity of freight calculated on labour of logistics transport industry (LTI); while number of FDI projects and operating FDI capital have impact, registered FDI capital does not have impact on productivity of passenger based on labour in LTI calculations; while registered FDI capital and number of FDI projects have impact, operating FDI capital does not impact productivity of freight calculated on capital in LTI; while registered FDI and operating FDI had impact, number of FDI projects does not impact gross domestic products.
\end{abstract}

Keywords: FDI; logistics; transport; HCM; Vietnam

\section{INTRODUCTION}

FDI is identified as an important economic component for economies as it promotes not only an economy but also the society to be developed together. On a global view, many studies show that FDI plays an important role in the economy of developing countries, reflected in the points like filling the gap in investment capital in terms of socioeconomic development, playing an important contribution to the technological modernization of the economy, Acquiring advanced management experience for faster and more efficient economic development, Creating more jobs for employees in order to reduce number of unemployment, building a team of highly skilled workers with a creative, disciplined and disciplined working spirit, increasing labour productivity, increasing income for workers, contributing to solving poverty, improving people's living standards, contributing to the increase of revenue for the state budget, promoting the development of the team of domestic enterprises, expanding international trade, developing markets and participating in global value chains.

In Vietnam, increasing the attraction of FDI projects with large capital scale from the leading developed countries in the world is a policy. Each year, Vietnam strives to attract about 20 billion USD and the rate of realized capital is about $70-75 \%$ of the registered capital. At the same time, it is a basis for promoting the development of domestic enterprises, contributing to the creation of domestic value chains.

[1] Foreign direct investment (FDI) from emerging markets to developing countries has increased significantly in recent decades. China's FDI to African economies are greater than those from the North FDI, and promoting effects of China's FDI which focuses on export and industrialization of local country. Especially, large amount of FDI from China to infrastructure of Africa is not only contributing to overall economic growth, but also enhancing local country's absorptive capacity in attracting and utilizing foreign capital (Kevin, 2021). [2] FDI consists of remittances that creates the positive mediating relationship in supporting new firm, institutions, transport infrastructure in recipient countries, governance and corruption (Eleni et al., 2021). [3] FDI plays the important role of having backward spreading on business organization's performances (Jen-Chung, 2021).

With the objective of assessing how FDI impact logistics transport development in HCM, the author uses multivariate regression.

\section{LITERATURE REVIEW}

[4] Opening the market can attract FDI. However, market opening may reduce welfare if a more pronounced entry distortion dominates the gain in consumer surplus. A country, which places sufficiently little weight on the interests of consumers, will object to market opening, even if welfare rises (Laszlo, 2020). [5] Kechagia (2019) stated that "The international allocation of capital flows is determined by various political, institutional, social and financial conditions. Recipient countries proceed to significant reforms in order to increase their attractiveness towards multinational companies and foreign investors".

[6] Intellectual property rights attracts more FDI in countries with small informal economies but not in countries with large informal economies. In institutionally strong countries, FDI are attracted as well as in countries 
with small informal economies but not in countries with large informal economies (Minsoo et al., 2018). [7] The institutional factors policy makers play an important role to attract FDI inflows, particularly during economic crises. Economic freedom has positive impact on FDI inflows. Protection of property rights, government integrity, monetary freedom, and financial freedom all also have a robustly positive effect on FDI (Fotini, 2019). [8] FDI holding for emerging economies to developed economies face specific institutional failures, such as weak or incomplete regulations. Quality of taxation, which highlights the crucial role of institutions for firms originating in developed economies lack sound institutions and plays an important role in terms of FDI (Constantina et al., 2019). [9] The institutional quality variables of economic freedom, how easy to do business and international country risk have a positive and significant impact on FDI inflows in Arab economies (Omar, 2018). [10] Hongwei et al. (2021) said that "Outward foreign direct investment impact positively on overall employment, it can provide significant benefits to a local country. Belt and Road Initiative has increased the employment elasticity and have attributed this to the fact that the Initiative has focused on the promotion of "horizontal" market-seeking outward foreign direct investment in infrastructure industries. Outward foreign direct investment aimed to upgrade the industrial structure tends to reduce the elasticity of employment with respect to outward foreign direct investment". [11] FDI inflows in emerging economies is promoted by divergence in business cycles-de-coupling between the two groups of countries fosters. De-industrialisation in developed economies increases FDI inflows into emerging economies, while the relative under-performance of developed countries will reduce it (Alina et al., 2014).

[12] There is evidence that the presence of Canadian provincial-level investment promotion agencies has been located in China that creases the likelihood of Chinese firms located in that Canadian province (John et al., 2015). [13]
Brazil, Russia, India, China and South Africa are recognized as the most developed economies from the emerging economies which offers to foreign investors a number of benefits such as young labour force, cheap labour force, natural resources and big markets. In these emerging economies FDI seem to have a positive impact by contributing to their development (Paula, 2015). [14] Shufeng et al. (2018) found that "Institutional mechanisms, such as the institutionally determined ownership restructuring and the different levels of subnational institutional development within the host emerging market, significantly shape the variation of FDI spreading effects on the productivity of local firms. This research highlights the importance of incorporating institutional effects in understanding the FDI spreading effects in emerging markets". [15] Sabina et al. (2015) supposed that "FDI contribute to economic growth predominantly through knowledge spreading, and that the higher level of technological development proxied by government and business Research \& Development expenditures is associated with better growth performance among transition economies. Essentially, by the way we measure FDI in this analysis and in the view of the integrated framework in which we study the relationship between FDI and economic growth, allows us to stipulate that the positive impact of FDI on economic growth is associated with more knowledge-capability and efficiency-seeking FDI". [16] Ownerships of block-shareholders in the parent firm like controlling family, non-family members, institutional investors, and equity stake in a subsidiary owned by the parent company are positively associated with FDI. The effects of parent firm and subsidiary ownership factors may substitute for each other with respect to their integrated effect on dealing with risks associated with FDI location decisions (Yung-Chih et al., 2015). [17] Both the size of the impact and the statistical significance of the indirect effects of FDI which namely is the productivity spreading, are lower than the direct effects due to foreign participation in corporate management by owning (Ichiro et al., 2016).

\section{METHODOLOGY}

- Study framework

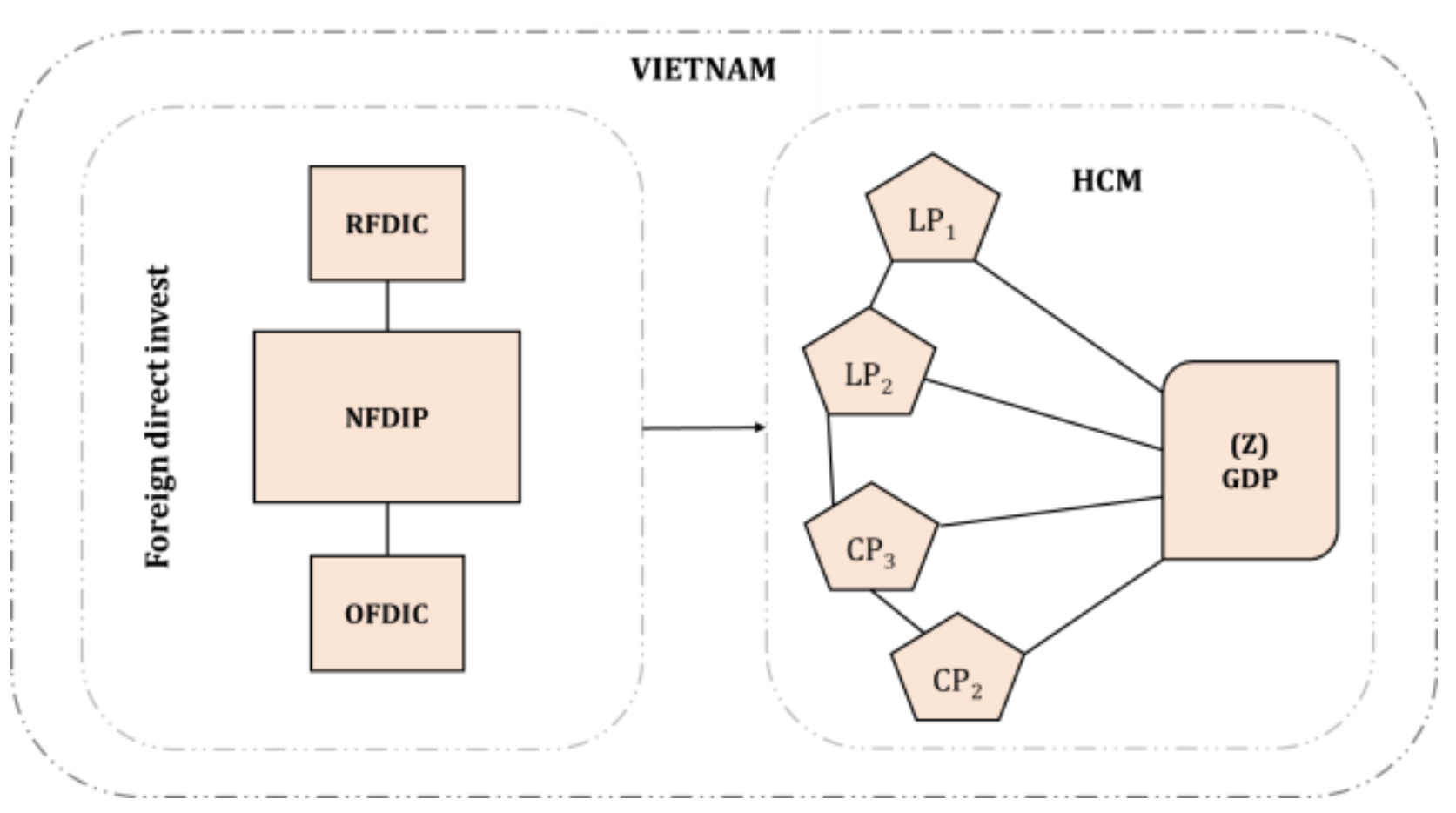




\section{Variables of study framework}

- Independent variables

RFDIC is registered foreign direct investment capital which is calculated on Vietnam's economy, unit is million US Dollar.

NFDIP is number of foreign direct investment projects which is calculated on Vietnam's economy, unit is projects.

OFDIC is operating foreign direct investment capital which is calculated on Vietnam's economy, unit is million US Dollar.

\section{- Dependent variables:}

$\mathrm{LP}_{1}$ is productivity of freight which is calculated on labour of logistics transport industry (LTI), the unit is thousand tons divided by total labour in LTI.

$\mathrm{LP}_{1}=\frac{\text { Total volume of feight in LTI that have been transported }}{\text { Total labour force in LTI }}$

$\mathrm{LP}_{2}$ is productivity of passenger that is calculated on labour in LTI, the unit is million people divided by total labour in LTI.

$\mathrm{LP}_{2}=\frac{\text { Total number of passenger in LTI who have been transported }}{\text { Total }}$

$\mathrm{CP}_{1}$ is productivity of freight which is calculated on capital in LTI, the unit is thousand tons divided by total labour in LTI.

$\mathrm{CP}_{1}=\frac{\text { Total volume of feight in LTI that have been transported }}{\text { Total capital in LTI }}$

$\mathrm{CP}_{2}$ is productivity of passenger that is calculated on labour in LTI, the unit is million people divided by total labour in LTI.

$\mathrm{CP}_{2}=\frac{\text { Total number of passenger in LTI who have been transported }}{\text { Total capital in LTI }}$ Total capital in LTI

$\mathrm{Z}$ is Gross domestic products.

\section{Multivariate regression model}

$\mathrm{LP}_{1}=\mathrm{h}_{0}+\mathrm{h}_{1}$ RFDIC $+\mathrm{h}_{2}$ NFDIP $+\mathrm{h}_{3}$ OFDIC $+\mathrm{g}$

$\mathrm{LP}_{2}=\mathrm{h}_{0}+\mathrm{h}_{1}$ RFDIC $+\mathrm{h}_{2}$ NFDIP $+\mathrm{h}_{3}$ OFDIC $+\mathrm{g}$ [2]

$\mathrm{CP}_{1}=\mathrm{h}_{0}+\mathrm{h}_{1}$ RFDIC $+\mathrm{h}_{2}$ NFDIP $+\mathrm{h}_{3}$ OFDIC $+\mathrm{g}$ [3]

$\mathrm{CP}_{2}=\mathrm{h}_{0}+\mathrm{h}_{1}$ RFDIC $+\mathrm{h}_{2}$ NFDIP $+\mathrm{h}_{3}$ OFDIC $+\mathrm{g}$

$\mathrm{Z}=\mathrm{h}_{0}+\mathrm{h}_{1}$ RFDIC $+\mathrm{h}_{2}$ NFDIP $+\mathrm{h}_{3}$ OFDIC $+\mathrm{g}$
Where

$\mathrm{h}_{\mathrm{o}}$ is the cut point between vertical axis and lines of regression.

$\mathrm{g}$ is other variables which are not RFDIC, NFDIP, OFDIC and this paper does not analyse them either.

As stated by Keshab (2015, p. 55) and Jeffrey (2020, p. 126), whereby:

$\mathrm{h}_{\mathrm{o}}+\mathrm{h}_{1}+\mathrm{h}_{2}+\mathrm{h}_{3}=0$, shows that MR models [1], [2], [3], [4],

[5] were not built suitably to the input data and these [1],

[2], [3], [4], [5] models do not have statistical significance.

$h_{0}+h_{1}+h_{2}+h_{3} \neq 0$, shows that MR models [1], [2], [3], [4],

[5] were built suitably to the input data and these [1], [2],

[3], [4], [5] models have statistical significance.

$\mathrm{h}_{1}, \mathrm{~h}_{2}, \mathrm{~h}_{3}>0$ means RFDIC, NFDIP, OFDIC impact LP1, LP2, $\mathrm{CP}_{1}, \mathrm{CP}_{2}, \mathrm{Z}$, respectively and separately.

$\mathrm{h}_{1}, \mathrm{~h}_{2}, \mathrm{~h}_{3}<=0$ means RFDIC, NFDIP, OFDIC do not impact $\mathrm{LP}_{1}, \mathrm{LP}_{2}, \mathrm{CP}_{1}, \mathrm{CP}_{2}, \mathrm{Z}$, respectively and separately.

THEORETICAL BAIS OF LOGISTICS TRANSPORTATION [18] Logistics is important for national competitiveness, especially in the context that globalization is being increased. There are several global indicators that have been developed related to national level logistics such as the World Bank's Logistics Performance Index (Ruth et al., 2021). [19] The digital economy may open new possibilities for optimizing the logistics transport in Russia, where the contribution of logistics transport in the GDP growth could reach 15-20 \% by 2020 (Elena et al., 2020). [20] Logistics transport is an essential activity for cities and involve complicated interactions between the public and private sectors. Cities are growing and logistics transport is becoming more important in economic field in almost all countries (Michael et al., 2021).

\section{DATA SOURCE}

The time series data was obtained between 2010 and 2020 from HCM Statistics Department and HCM Statistical Yearbook. 


\section{STUDY RESULTS}

TABLE 1: MR results of model [1] $\mathrm{LP}_{1}$, model [2] $\mathrm{LP}_{2}$, and model [3] $\mathrm{CP}_{1}$

\begin{tabular}{|c|c|c|c|c|c|c|c|c|c|c|c|}
\hline \multicolumn{4}{|c|}{ [1] $\mathrm{LP}_{1}=\mathrm{h}_{0}+\mathrm{h}_{1} \mathrm{RFDIC}+\mathrm{h}_{2} \mathrm{NFDIP}+\mathrm{h}_{3}$ OFDIC } & \multicolumn{4}{|c|}{ [2] $\mathrm{LP}_{2}=\mathrm{h}_{0}+\mathrm{h}_{1}$ RFDIC $+\mathrm{h}_{2}$ NFDIP $+\mathrm{h}_{3}$ OFDIC } & \multicolumn{4}{|c|}{ [3] $\mathrm{CP}_{1}=\mathrm{h}_{0}+\mathrm{h}_{1}$ RFDIC $+\mathrm{h}_{2}$ NFDIP $+\mathrm{h}_{3}$ OFDIC } \\
\hline \multicolumn{2}{|c|}{ R square (RS) } & \multicolumn{2}{|c|}{$0.77970499(78 \%)$} & \multicolumn{2}{|c|}{ R square (RS) } & \multicolumn{2}{|c|}{$0.8098104(81 \%)$} & \multicolumn{2}{|c|}{ R square (RS) } & \multicolumn{2}{|c|}{$0.360788(36 \%)$} \\
\hline \multicolumn{2}{|c|}{ Adjusted R Square (ARS) } & \multicolumn{2}{|c|}{$0.68529284(69 \%)$} & \multicolumn{2}{|c|}{ Adjusted R Square (ARS) } & \multicolumn{2}{|c|}{$0.72830057(73 \%)$} & \multicolumn{2}{|c|}{ Adjusted R Square (ARS) } & \multicolumn{2}{|c|}{$0.08684(8.7 \%)$} \\
\hline \multicolumn{2}{|c|}{ Significance F (SF) } & \multicolumn{2}{|c|}{0.01063184} & \multicolumn{2}{|c|}{ Significance F (SF) } & \multicolumn{2}{|c|}{0.00644661} & \multicolumn{2}{|c|}{ Significance F (SF) } & \multicolumn{2}{|c|}{0.3426986} \\
\hline \multirow{2}{*}{$\begin{array}{c}\text { Independent } \\
\text { variables }\end{array}$} & Coefficients & $\begin{array}{c}\text { Value of } \\
\text { Coefficients }\end{array}$ & P-Value & \multirow{2}{*}{$\begin{array}{c}\text { Independent } \\
\text { variables }\end{array}$} & Coefficients & $\begin{array}{c}\text { Value of } \\
\text { Coefficients }\end{array}$ & P-Value & \multirow{2}{*}{$\begin{array}{c}\text { Independent } \\
\text { variables }\end{array}$} & Coefficients & $\begin{array}{c}\text { Value of } \\
\text { Coefficients }\end{array}$ & P-Value \\
\hline & $\mathrm{h}_{0}$ & 0.27634588 & 0.33745593 & & $\mathrm{~h}_{0}$ & 0.01798782 & 0.56581332 & & $\mathrm{~h}_{0}$ & 0.65716126 & 0.11399974 \\
\hline RFDIC & $\mathrm{h}_{1}$ & 4.9292E-05 & 0.75802986 & RFDIC & $\mathrm{h}_{1}$ & $-1.679 \mathrm{E}-05$ & 0.35926355 & RFDIC & $\mathrm{h}_{1}$ & 0.00019592 & 0.37902041 \\
\hline NFDIP & $\mathrm{h}_{2}$ & $1.4709 \mathrm{E}-05$ & 0.29439344 & NFDIP & $\mathrm{h}_{2}$ & $1.3028 \mathrm{E}-06$ & 0.39680521 & NFDIP & $\mathrm{h}_{2}$ & $1.4682 \mathrm{E}-05$ & 0.4317793 \\
\hline OFDIC & $\mathrm{h}_{3}$ & $-1.118 E-05$ & 0.83625808 & OFDIC & $\mathrm{h}_{3}$ & 5.4558E-06 & 0.37798432 & OFDIC & $\mathrm{h}_{3}$ & $-6.698 E-05$ & 0.37492756 \\
\hline
\end{tabular}


[1] LP1 = h0 + h1RFDIC + h2NFDIP + h30FDIC With RS $=0.77970499(78 \%)$, ARS $=0.68529284(69 \%)$.

Input data of model [1] LP1 was explained $69 \%$ by output result of regression. ho $+\mathrm{h} 1+\mathrm{h} 2+\mathrm{h} 3=0.276398696 \neq 0$. Model has $P$-Value of ho $+\mathrm{h} 1+\mathrm{h} 2+\mathrm{h} 3$ are 0.33745593 , $0.75802986,0.29439344$, and 0.83625808 , respectively. They can be decided as the model [1] LP1 was built to be suitable to input data and model [1] LP1 has statistical significance at the level 0.01063184 .

Coefficients Value of independent variables $>0$ consists of h1 $=4.9292 \mathrm{E}-05, \mathrm{~h} 2=1.4709 \mathrm{E}-05$. For that reason, RFDIC and NFDIP has an impact on LP1.

Coefficients Value of independent variables $<0$ consists of $\mathrm{h} 3=-1.118 \mathrm{E}-05$. For that reason, OFDIC does not have an impact on LP1.

[2] LP2 = h0 + h1RFDIC + h2NFDIP + h3OFDIC

With RS $=0.8098104(81 \%)$, ARS $=0.72830057(73 \%)$.

Input data of model [2] LP2 was explained at $73 \%$ by output result of regression: ho $+\mathrm{h} 1+\mathrm{h} 2+\mathrm{h} 3=$ $0.017977787 \neq 0$. Model has $P$-Value of ho $+\mathrm{h} 1+\mathrm{h} 2+\mathrm{h} 3$ to be $0.56581332,0.35926355,0.39680521$, and 0.37798432 , respectively. This can be decided that the model [2] LP2 was built to be suitable to input data and model [2] LP2 has statistical significance at the level 0.00644661 .
Coefficients Value of independent variables $>0$ consists of h2 $=1.3028 \mathrm{E}-06, \mathrm{~h} 3=5.4558 \mathrm{E}-06$. For that reason, NFDIP and OFDIC have an impact on LP2.

Coefficients Value of independent variables $<0$ consists of $\mathrm{h} 1=-1.679 \mathrm{E}-05$. For that reason, RFDIC does not have an impact on LP2.

[3] CP1 = h0 + h1RFDIC + h2NFDIP + h3OFDIC With RS $=0.360788(36 \%)$, ARS $=0.08684(8.7 \%)$.

Input data of model [3] CP1 was explained $96 \%$ by output result of regression. ho $+\mathrm{h} 1+\mathrm{h} 2+\mathrm{h} 3=0.657304878 \neq 0$. Model has $P$-Value of ho $+\mathrm{h} 1+\mathrm{h} 2+\mathrm{h} 3$ as 0.11399974 , $0.37902041,0.4317793$, and 0.37492756 , respectively. It can be decided that the model [3] CP1 was built to be suitable to input data and model [3] with CP1 has statistical significance at the level 0.3426986 .

Coefficients Value of independent variables $>0$ consists of $\mathrm{h} 1=0.00019592, \mathrm{~h} 2=1.4682 \mathrm{E}-05$. For that reason, RFDIC and NFDIP have an impact on CP1.

Coefficients Value of independent variables $<0$ consists of h3 $=-6.698 \mathrm{E}-05$. For that reason, OFDIC does not have an impact on CP1.

TABLE 2: MR results of model [4] CP2 and model [5] Z

\begin{tabular}{|c|c|c|c|c|c|c|c|}
\hline \multicolumn{4}{|c|}{ [4] $\mathrm{CP}_{2}=\mathrm{h}_{0}+\mathrm{h}_{1}$ RFDIC $+\mathrm{h}_{2}$ NFDIP $+\mathrm{h}_{3}$ OFDIC } & \multicolumn{4}{|c|}{$[5] \mathrm{Z}=\mathrm{h}_{0}+\mathrm{h}_{1}$ RFDIC $+\mathrm{h}_{2}$ NFDIP $+\mathrm{h}_{3}$ OFDIC } \\
\hline \multicolumn{2}{|l|}{ R square (RS) } & \multicolumn{2}{|c|}{$0.15471823(15 \%)$} & \multicolumn{2}{|l|}{ R square (RS) } & \multicolumn{2}{|c|}{$0.972036(97 \%)$} \\
\hline \multicolumn{2}{|c|}{ Adjusted R Square (ARS) } & \multicolumn{2}{|c|}{$-0.2075454(-20 \%)$} & \multicolumn{2}{|c|}{ Adjusted R Square (ARS) } & \multicolumn{2}{|c|}{$0.96005143(96 \%)$} \\
\hline \multicolumn{2}{|c|}{ Significance F (SF) } & \multicolumn{2}{|l|}{0.73989018} & \multicolumn{2}{|c|}{ Significance F (SF) } & \multicolumn{2}{|c|}{$8.4206 \mathrm{E}-06(0.0000084)$} \\
\hline \multirow{2}{*}{$\begin{array}{c}\text { Independent } \\
\text { variables }\end{array}$} & Coefficients & $\begin{array}{c}\text { Value of } \\
\text { Coefficients }\end{array}$ & P-Value & \multirow{2}{*}{$\begin{array}{c}\text { Independent } \\
\text { variables }\end{array}$} & Coefficients & $\begin{array}{c}\text { Value of } \\
\text { Coefficients }\end{array}$ & P-Value \\
\hline & $\mathrm{h}_{0}$ & 0.08447904 & 0.09107362 & & $\mathrm{~h}_{0}$ & -16856.691 & 0.45811583 \\
\hline RFDIC & $\mathrm{h}_{1}$ & $9.7121 \mathrm{E}-06$ & 0.70621093 & RFDIC & $\mathrm{h}_{1}$ & 19.1028594 & 0.16454754 \\
\hline NFDIP & $\mathrm{h}_{2}$ & $1.2179 \mathrm{E}-06$ & 0.57768198 & NFDIP & $\mathrm{h}_{2}$ & -0.1070008 & 0.92080097 \\
\hline OFDIC & $\mathrm{h}_{3}$ & $-4.136 \mathrm{E}-06$ & 0.63664889 & OFDIC & $\mathrm{h}_{3}$ & 4.1720151 & 0.35031571 \\
\hline
\end{tabular}

[4] CP2 = h0 + h1RFDIC + h2NFDIP + h3OFDIC

Model [4] CP2 has RS = 0.972036 (97\%),

ARS $=-0.2075454(-20 \%)$ which is to show that the output result of regression has not been able to explain the input data. It can be decided that model [4] CP2 has not been built to be suitable to the input data, so there is no statistical significance of model [4] CP2.

[5] Z = h0 + h1RFDIC + h2NFDIP + h30FDIC With RS $=0.99621996(99.6 \%)$, ARS $=0.96005143(96 \%)$.

Input data of model [5] $\mathrm{Z}$ was explained $96 \%$ by output result of regression. ho $+\mathrm{h} 1+\mathrm{h} 2+\mathrm{h} 3=-16833.52345 \neq 0$. P-Value has ho + h1 + h2 + h3 are $0.45811583,0.16454754$, 0.92080097 , and 0.35031571 , respectively. This can be decided as the model [5] Z to be built suitably to input data and model [5] $\mathrm{Z}$ with statistical significance at the level 8.4206E-06 (0.0000084).

Coefficients Value of independent variables $>0$ consists of $\mathrm{h} 1=19.1028594, \mathrm{~h} 3=4.1720151$. For that reason, RFDIC and OFDIC have an impact on $\mathrm{Z}$.
Coefficients Value of independent variables $<0$ consists of h2 $=-0.1070008$. For that reason, NFDIP does not impact on $\mathrm{Z}$

\section{DISCUSSION}

From the research result, model [1] LP1, model [2] LP2, model [3] CP1, and model [5] Z have ARS $=0.68529284$ (69\%), ARS $=0.72830057(73 \%)$, ARS $=0.08684(8.7 \%)$, and ARS $=0.96005143(96 \%)$, which is to mean that the input data of four models have been explained by $69 \%, 73 \%$, $8.7 \%$ at the levels of $0.01063184,0.0064466,0.3426986$, 8.4206E-06 (0.0000084), respectively.

Model [4] CP2 has ARS $=-0.2075454(-20 \%)$, which may connote that the method of input data collection has not been proper, with ARS $=-20 \%<0$, it can be decided that there is no statistical significance of model [4] CP2.

Model [1] LP1 has (RFDIC) h1 = 4.9292E-05 and (NFDIP) $\mathrm{h} 2=1.4709 \mathrm{E}-05$ impact on LP1. (OFDIC) h3 = -1.118E-05 does not have an impact on LP1. Model [2] LP2 has (NFDIP) $\mathrm{h} 2=1.3028 \mathrm{E}-06$ and (OFDIC) h3 = 5.4558E-06 impact on LP2. (RFDIC) h1 = -1.679E-05 does not have an impact on LP2. Model 
[3] CP1 has (RFDIC) h1 $=0.00019592$ and (NFDIP) h2 = 1.4682E-05 have an impact on CP1. (OFDIC) h3 $=-6.698 \mathrm{E}-$ 05 does not have an impact on CP. And model [5] Z has (RFDIC) h1 = 19.1028594 and (OFDIC) h3 = 4.1720151 impact on Z. (NFDIP) h2 $=-0.1070008$ does not have an impact on $\mathrm{Z}$.

\section{CONCLUSION}

Model [1] LP1: While RFDIC which is calculated on Vietnam's economy and NFDIP which is calculated on Vietnam's economy impact, OFDIC which is calculated on Vietnam's economy does not impact on LP1 productivity of freight which is calculated on LTI.

Model [2] LP2: While NFDIP which is calculated on Vietnam's economy and OFDIC which is calculated on Vietnam's economy impact, RFDIC which is calculated on Vietnam's economy does not impact on LP2 productivity of passenger that is calculated on labour in LTI.

Model [3] CP1: While RFDIC which is calculated on Vietnam's economy and NFDIP which is calculated on Vietnam's economy impact, OFDIC which is calculated on Vietnam's economy does not impact on CP1 productivity of freight which is calculated on capital in LTI.

Model [5] Z: While RFDIC which is calculated on Vietnam's economy and OFDIC which is calculated on Vietnam's economy impact, NFDIP which is calculated on Vietnam's economy does not impact on $\mathrm{Z}$ gross domestic products.

\section{Acknowledgement}

This research is funded by University of Economics and Law, Vietnam National University Ho Chi Minh City / VNU-HCM.

\section{REFERENCE}

[1] Kevin H.Zhang, 2021. How does South-South FDI affect host economies? Evidence from China-Africa in 20032018. International Review of Economics \& Finance. Volume 75, September 2021, Pages 690-703.

[2] Eleni E.N.Piteli, Mario Kafouros, Christos N.Pitelis, 2021. Follow the people and the money: Effects of inward FDI on migrant remittances and the contingent role of new firm creation and institutional infrastructure in emerging economies. Journal of World Business. Volume 56, Issue 2, February 2021, 101178.

[3] Jen-Chung Mei, 2021. Refining vertical productivity spillovers from FDI: Evidence from 32 economies. International Review of Economics \& Finance. Volume 74 July 2021, Pages 176-191.

[4] Laszlo Goerke, 2020. A political economy perspective on horizontal FDI in a dynamic Cournot-oligopoly with endogenous entry. European Journal of Political Economy. Volume 63, June 2020, 101897.

[5] Kechagia Polyxeni, Metaxas Theodore, 2019. An empirical investigation of FDI inflows in developing economies: Terrorism as a determinant factor. The Journal of Economic Asymmetries. Volume 20, November 2019, e00125.

[6] Minsoo Lee, Joseph D.Alba, DonghyunPark, 2018 Intellectual property rights, informal economy, and FDI into developing countries. Journal of Policy Modeling. Volume 40, Issue 5, September-October 2018, Pages 1067-1081.

[7] Fotini Economou, 2019. Economic freedom and asymmetric crisis effects on FDI inflows: The case of four South European economies. Research in International Business and Finance. Volume 49, October 2019, Pages 114126.
[8] Constantina Kottaridi, Dimitris Giakoulas, Dimitris Manolopoulos, 2019. Escapism FDI from developed economies: The role of regulatory context and corporate taxation. International Business Review. Volume 28, Issue 1, February 2019, Pages 36-47.

[9] Omar Ghazy Aziz, 2018. Institutional quality and FDI inflows in Arab economies. Finance Research Letters. Volume 25, June 2018, Pages 111-123.

[10] Hongwei Liao, Liangping Yangb, Shuanping Dai et al., 2021. Outward FDI, industrial structure upgrading and domestic employment: empirical evidence from the Chinese economy and the belt and road initiative. Journal of Asian Economics 74 (2021) 101303.

[11] Alina Kudina, Christos Pitelis, 2014. Deindustrialisation, comparative economic performance and FDI inflows in emerging economies. International Business Review. Volume 23, Issue 5, October 2014, Pages 887-896.

[12] John Anderson, Dylan Sutherland, 2015. Developed economy investment promotion agencies and emerging market foreign direct investment: The case of Chinese FDI in Canada. Journal of World Business. Volume 50, Issue 4, October 2015, Pages 815-825.

[13] Paula Nistor, 2015. FDI implications on BRICS economy growth. Procedia Economics and Finance 32 (2015) $981-985$.

[14] Shufeng (Simon) Xiao, Byung Il Park, 2018. Bring institutions into FDI spillover research: Exploring the impact of ownership restructuring and institutional development in emerging economies. International Business Review. Volume 27, Issue 1, February 2018, Pages 289-308.

[15] Sabina Silajdzic, Eldin Mehic, 2015. Knowledge spillovers, absorptive capacities and the impact of FDI on economic growth: empirical evidence from transition economies. Procedia - Social and Behavioral Sciences 195 (2015) $614-623$.

[16] Yung-Chih Lien, Igor Filatotchev, 2015. Ownership characteristics as determinants of FDI location decisions in emerging economies. Journal of World Business. Volume 50, Issue 4, October 2015, Pages 637-650.

[17] Ichiro Iwasaki, Masahiro Tokunaga, 2016. Technology transfer and spillovers from FDI in transition economies: A meta-analysis. Journal of Comparative Economics. Volume 44, Issue 4, November 2016, Pages 1086-1114.

[18] Ruth Banomyong, David B. Grant, Paitoon Varadejsatitwong et al., 2021. Developing and validating a national logistics cost in Thailand. Transport Policy $\mathrm{xxx}$ (xxxx)xxx.https://doi.org/10.1016/j.tranpol.2021.04.026.

[19] Elena G. Popkova, Bruno S.Sergi, 2020. A Digital Economy to Develop Policy Related to Transport and Logistics. Predictive Lessons from Russia. Land Use Policy. Volume 99, December 2020, 105083.

[20] Michael Browne, José Holguin-Veras, JulianAllen, 2021. Urban Logistics and Freight Transport. International Encyclopedia of Transportation. 2021, Pages 178-183. 